\title{
Analysis on the teaching reform of basic computer courses in Colleges
}

\author{
Zhang Yanlin \\ Computer Science Department, Wenzhou Vocational \& Technical College, \\ Wenzhou 325035, China
}

\begin{abstract}
The teaching reform in basic computer course is the important measure of deepening the teaching reform and improving the educational informationization. Combined with our school basic computer teaching, this article discusses the teaching reform of basic computer course from the teaching objectives, teaching content, teaching mode, teaching method, examination method and so on, and strives to improve teaching quality and teaching effect of college basic computer course.
\end{abstract}

Keywords: basic computer; teaching reform; teaching quality

\section{Introduction}

With the advance of society and technology, fundamental education of computer for college starts from scratch and is gradually expanding from single unit to scope in China. Fundamental computer education has received its golden age. Fundamental computer education for college should not only improve the computer application skill of students, but must take the responsibility to improve the information quality of college students. As computer is only one of many majors provided by colleges, fundamental computer education can provide basic knowledge, application skills and qualities for students from other majors. The course aims to train the awareness and innovative ability to analyze and solve problems with computer, improve computer quality of students, and prepare students to solve the matters of their majors with computer skills and establish the foundation for their future development.

\section{Significance of Basic Computer Ed- ucation for College}

Nowadays, computer IT technology, as one of the various uprising technologies, which has developed fastest and has been applied most widely, is of the most significance to economic society. As for the education in information age, course content of college computer basis should have an adjustment according to the characteristics of quality education which should penetrate into the education of computer knowledge. Besides computer basis, education should be oriented to the cultivation of ability to obtain and process information with computer, as well as creating and exchanging information, so that students can effectively apply information tool and resources to improving their learning way, and establish the thought of solving problems with information tool. This course should be promoted to the level of enhancing information skill and qualities from application of basic knowledge to establish an example for other courses in terms of information quality education. 


\section{Computer Basis of New Comers of College}

There is a great diversity of computer knowledge in new comers of college. As for my school, students come from areas around the nation, including coastal cities and inland areas in dilemma; some students have mastered basic knowledge and skills of computer in senior high school and some still feel strange to computer. According to the questionnaire surveys of the author throughout years, students pick up computer knowledge mainly from internet access, email exchange, online games and chat before they go to college; systematic course of computer basis is only available in a minority of developed areas, but the contents are very shallow and cannot still achieve the goal of college computer teaching.

\section{Reform of Basic Computer Course for College}

The reform of course should concentrate on the cultivation of sense of social responsibility, information awareness and practical ability of students.

\subsection{Goal of Reform}

Each department of college should orient the fundamental teaching of computer to ability training and application. Fundamental teaching of computer in college is to provide this modernized intelligent tool for students through the learning of course and establish solid foundation for the study of consequent courses and entry into society. In the organization of teaching activity, firstly, we should instruct students learning methods to improve their self-learning ability. As computer technology is developing rapidly and the knowledge learnt in school is not always up-to-date, students must improve the learning ability to catch up with the developing computer technology.
According to the computer basis of college students in senior high school, the teaching of fundamental computer course of non-computer departments closely integrates the demand of future work and the major courses of students. Firstly, all the students can be categorized into two majors, arts and science. Arts include finance \& accounting, industry \& commerce, humanity; science includes electrics, machinery and construction engineering. Different fundamental computer courses are provided for different majors. For example, departments of finance \& accounting, industry \& commerce, and humanity are provided with "Advanced Application of Office Software"; construction engineering department is provided with "Graph Fabrication and Processing". Even for the same course, the teaching goal will vary with future occupations of students. For example, the office course of finance \& accounting department concentrates on the application of excel functions to meet the future demands of students at financial and accounting posts; the office course of humanity focuses on the application of Word in administrative office to meet the future demand of students in administration. Different majors are bound to different teaching goals.

\subsection{Teaching Content Reform}

Throughout the years, basic computer education for college is basically organized by 3 levels, computer culture, computer technology and computer application. Great achievements have been made by colleges in the first level. The content of this level mainly includes operation system, word process, e-form, multimedia design, internet, email and so on. This is disadvantageous to the perfection of knowledge structure and sensory understanding of computer hardware system.

In addition to the course of computer basis regulated by ministry of education 
for non-computer majors in recent years, our school has added some public selective courses, like "Computer Basis", "Computer OA Grade 2", "Flash Plane Design" and "Internet Application" in self-learning period at night and afterschool activities in the afternoon to meet the demand of students with different interests in different majors.

\subsection{Teaching Mode Reform}

The teaching mode, which is basic on computer, network and multimedia modern education technology, must embody the function of modern multimedia basic on computer and network, and convert teaching information into hyper text. The teaching strategy supported by internet and campus network can shape the advanced cognitive ability of students, improve the vitality of multimedia technology during teaching. Computer and network can provide a mass of information and understanding for students within a short period and communicate an ocean of information between teacher and student, student and student. Since 2009, the basic computer course of our school has been organized in computer room. Teachers give lecture by the mode "projection + broadcast + computer practice", which can greatly improve the enthusiasm and learning effect of students.

\subsection{Teaching Method Reform}

Computer basis is the course of practice and cannot be without practice. Therefore, we have changed the traditional instruction-led teaching method and given special emphasis to "refined instruction and more practice". "Refine Instruction" means we will design different application cases in class teaching. As class teaching cannot touch all aspects, we are mainly to reveal the key and difficulty of case and tell students the methods of learning and basic knowledge, so that they can learn by themselves. "More
Practice" means more practical operations for students. We start with training the operation skill of students and provide more opportunities for students to practice and think to improve the precision, flexibility and coordination of operation. For example, part of contents of Windows and Office is instructed in computer room where students practice while listening. Students are given intuitionistic lecture combined with image and text to facilitate the understanding and memorizing. The effect is very good.

As new college comers will have certain difference in computer level, fundamental teaching of computer should have a certain strategy. We adopt grading teaching according to the practical situations of students. New comers are given a grading examination and then we will classify them into class $\mathrm{A}, \mathrm{B}$, and $\mathrm{C}$ according to the result of examination. Students of class A can have a exemption of basic computer course; students of class $\mathrm{B}$ do not have to attend the lecture of basic computer course, but must complete related comprehensive assignments and attend the final examination of this course; students of class $\mathrm{C}$ must fully attend the lecture of basic computer course and take examination.

\subsection{Evaluation Method Reform}

As basic course of computer is an applied subject, written examination alone is not sufficient to reflect the practical ability of students. Most tests are to evaluate the understanding of knowledge, not the ability to solve practical problems. The existence of exam-oriented teaching will seriously affect the cultivation of innovative talents. Traditional examinations make students expert in theory, but not in practical operation. The way of learning for exam cannot mobilize the enthusiasm of students, nor can it stimulation the creativity of students. This evaluation method goes opposite with quality education. Our 
school always gives emphasis to practical operation ability of students, so the evaluation methods of basic course of computer will be arranged as follow:

- Highlight the evaluation of in-class operation skill and experimental skill. We will give some questions to evaluate operation skill and experimental skill in experimental lesson and a space for students to exert their talents. Students will become active in learning and the owner of examination.

- Concentrate on the evaluation of innovative ability to solve a project. Some practical projects will be provided for students to solve with the basic computer knowledge they have learnt. Students who make creative attempts will obtain high score. This way will stimulate the enthusiasm and learning desire of students, and provide opportunities for them to show talents and fully exert their imagination and creativity, and thereby produce creative talents.

- Evaluate the skills of students and mastership of knowledge in multiple ways. We provide the website of basic computer course for students, as well as the columns of learning, dialog, software issuance and so on. Participators are given scores which are treated as part of usual academic performance calculated in total evaluation score, so that students can develop the ability to obtain knowledge and information through multiple channels.

\section{Conclusion}

In this century featured by high informationization degree, social informationization is developing in depth and breadth and computer technology is combined with many professions greatly enriching the teaching methods and contents of majors. Each major raises increasing demands for computer application abilities of students, so the basic computer education becomes extremely important. Only by comprehensive and profound reform of computer basis for college and actively exerting the instructive function of teachers, can we make students learn with assignments and questions, stimulate their enthusiasm toward computer knowledge, mobilize the learning initiative and fully exert the subjective initiative of students. Focus of teaching should be transferred to the training of application ability and creativity to comprehensively improve the application ability of computer, establish solid foundation for further development of students in their positions, and produce more highquality talents of computer application for society.

\section{Reference}

[1] Ji Ning, Improvement and Analysis of Teaching Methods of Basic Computer Course in Higher Vocational Education $[\mathrm{J}]$, Information and Computer, 2010.12;

[2] Xubing, Brief Analysis on Reform and Discussion of Teaching of Basic Computer Course [J], College Education, 2012.8;

[3] Yu Xiumei, Teaching Reform and Education Informationization of Basic Computer Course for Non-Computer Majors [J], journal of Dongguan University of Technology, 2004.2;

[4] Han Baoqing, Construction of Open Teaching System of Basic Computer Course [J], Computer Education, 2011.10;

[5] Meng Xiaopei, Enhancing Teaching Reform and Improve the Education Quality of Basic Computer Course [J], China Adult Education, 2008. 